\section{Silvio Berlusconi \\ i Den Sorte Diamant}

I forairet 2013 arrangerede Det Kongelige Bibliotek en foredragsrakke under titlen "Kontroversielle politikere i det 20. og 21. århundrede" og inviterede her en rakke danske historikere til at prosentere deres forskning. Foredraget om den tidligere italienske regeringschef Silvio Berlusconi bringes her i sin oprindelige form som talepapir og er kun andret og praciseret på nogle mindre, uvasentlige punkter.

af universitetslektor, dr.phil. Gert Sørensen, Institut for Engelsk, Germansk og Romansk, Italiensk afdeling, Københavns Universitet

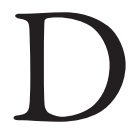
et er et udsøgt selskab, som Silvio Berlusconi (f. 1936) er med i her i Det Kongelige Biblioteks foredragsrække over markante politiske ledere i det 20. århundrede, om end han næppe vil finde det passende at blive nævnt sammen med Stalin og Goebbels. Bortset fra Kennedy er de alle knyttet til Europas turbulente historie, og de har alle drevet de modsætninger, der altid har karakteriseret Europas lange identitets- og kulturhistorie, til deres yderste og ofte med en egentlig katastrofe til følge.

Med Margaret Thatchers død tidligere på måneden (den 8. april 2013) er Berlusconi den eneste af de her behandlede politikere, der endnu er i live og faktisk fortsat er et vigtigt omdrejningspunkt i italiensk politik. Mange havde ellers dømt ham ude, da der blev udskrevet valg i slutningen af 2012. Berlusconi havde endda forinden nået at melde ud, at han

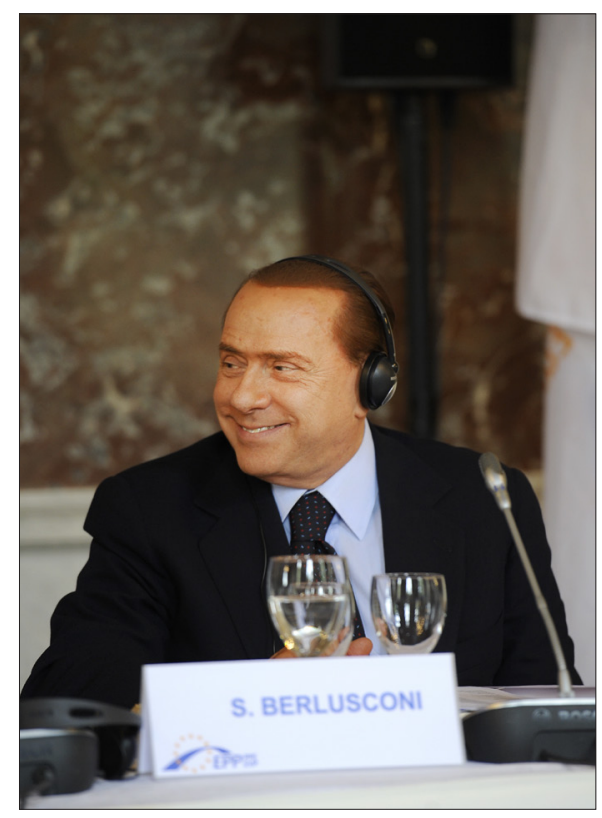

ikke ville stille op. Det fortrød han så, og fik ved det netop overståede valg den 24.-25. februar i år [2013] et resultat, der lå noget over, hvad meningsmålingerne havde spået, men langt under resultatet ved sidste valg i 2008. Det gør det naturligvis ikke nemmere at fà svar på de mange spørgsmål, der melder sig omkring en så kontroversiel person som Berlusconi, altså hvem er han, hvad står han for, hvorfra kommer han og hvor har han bragt Italien hen, osv. Med Berlusconi befinder vi os altså fortsat midt i en på én gang personlig historie med alle gossip-kulturens ingredienser: løsslupne bunga-bunga-fester og dyre skilsmisser, og et stykke italiensk og europæisk samtidshistorie.

Den kendte middelalderhistoriker Ernst Kantorowicz opererer et sted med konge- og fyrstefigurens to kroppe: Den ene krop er den, der er bestemt af fyrstens biologiske liv, der fødes og dør og følger 
livets cyklus, mens den anden krop er defineret ved den institution eller af den rolle, som den konkrete, biologiske fyrste-person beklæder, og som fortsat er der, når en fyrste dør eller fratræder. Hvor vil jeg hen med det? Sagen er den, at når man som kulturhistoriker kommer med et bud på, hvem, osv., Berlusconi er, så er det umiddelbart indlysende, at det er et konkret livsudkast, vi har at gøre med, selv om det er de færreste af os, der kender ham eller overhovedet har set ham i levende live. I denne henseende er Berlusconi efterhånden højt oppe i alderen. Han blev født i 1936, og årene og hans enorme arbejdspensum har tydeligt mærket hans fysiske fremtoning og gjort ham meget sårbar i mediernes skarpe lys, der ellers altid har omkranset ham med en aura.

Men nok så vigtigt. Det er som et ikon, et skærmbillede, de fleste af os kender Berlusconi, og så endda sjældent $\mathrm{i}$ hel figur, da han ofte ses omgivet af mennesker eller står på en talerstol, der kun viser overkroppen og skærer ham over på midten. Mit eget arbejde med Berlusconi vil jeg ikke klassificere som en egentlig biografi i traditionel forstand, der gerne følger dannelsesromanens fortællestruktur og begynder med de tidligste år for så at følge hovedpersonen gennem modningsårene og frem til manddomsårene og den afsluttende død. Jeg har snarere bestræbt mig på at indkredse dette quid, det noget, der gør, at Berlusconi er noget mere end bare et interessant liv. Han lægger navn til en -isme, berlusconismen. Han giver i sin måde at agere på, at tænke på, at performe på et signalement af en tid, ikke blot i den forstand at han repræsenterer denne tid, men også i den forstand at han eksponerer den og forstærker nogle træk i den. Han løsgør nogle tendenser i tiden, som det pludseligt viser sig, der ikke rigtigt er nogen modvirkninger imod. Det bliver naturligvis en historie om Italien, der går tilbage til 1980'ernes begyndelse, da Berlusconi for alvor træder frem på den store scene og bliver kendt som den, der for alvor indførte det private, reklamefinansierede TV i Italien, for siden at blive en helt afgørende del af den politiske og kulturelle dagsorden. Men dette stykke nyere italienske historie, som vi her skal belyse nærmere, har imidlertid også nogle mere generelle aspekter, der faktisk også vedrører os selv i Danmark.

Man kan naturligvis vælge at gøre som en tidligere dansk udenrigsminister og rubricere Berlusconi som "ham idioten i Italien”. Så kan vi vel slutte her og stille os tilfreds med det, hvis ikke den italienske case netop byder sig til også som et spejl, vi kan holde op foran os selv og så spørge, hvordan det egentlig går her, når det gælder hele den forvandling af den politiske kultur, som - lad os sige - berlusconismen har tydeliggjort.

At betegne Berlusconi som en idiot udtrykker for mig at se lidt af en intellektuel bekvemmelighed, som megen polemik er, men som vel egentlig dækker over en afmagt i forståelsen af fænomenet. Lad os derfor begynde med en portrætskitse, hvori Giuseppe Fiori, forfatter til en af de første mere traditionelle biografier om Berlusconi, leverer dette rigt facetterede signalement af vor hovedperson, der angiveligt besidder: "Talentet, modet, kreativiteten, foretagsomheden, færten for forretninger, optimismen, manien med at gøre sig bemærket, den frenetiske adfærd, stædigheden, omskifteligheden, uforudsigeligheden, fordomsfriheden, tvetydigheden, den sikre færden i hemmelighedernes labyrint [...], klanfølelsen, 
smagen for at kommandere, vanen med at samle personer omkring sig, opmærksomheden mod den vindende gestus, viljen til at behage, den enestående arbejdsevne". Man skal givet have fat i denne 'opdaterede' version af renæssancemenneskets alsidighed for overhovedet at kunne forklare, at Berlusconi nu i mere end tredive år har været et omdrejningspunkt for det første i finanskoncernen Fininvest (en af Italiens største og med interesser inden for bl.a. byggeri, bankvæsen, presse og TV), for det andet i medieverdenen og endelig for det tredje i den politiske verden, som han erobrede med sit parti Forza Italia ved valget i 1994, altså ti år efter at han havde konsolideret sin monopollignende position på det private mediemarked.

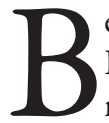
erlusconi har udgjort en forskel. Der er et før og et efter Berlusconi, men kun fordi han til forskel fra så mange andre havde talentet, foretagsomheden og snarrådigheden - nogle ville sige frækheden -, der skulle til. Han besad akkurat den virtù, som Machiavelli mente, en fyrste skulle besidde, nemlig den evne til at forholde sig til de muligheder, en given situation åbnede, og slå til med en vindende gestus. Det er næppe tilfældigt, at Berlusconi faktisk udgav Machiavellis hovedværk Il Principe, der fylder 500 år i år. Han skrev selv flere forord til udgaven, hvori han fremhæver, hvorledes Machiavelli i sit værk gør viljen til magt eller statsfornuften (it. la ragione di Stato) til det afgørende og højest vægtede handlingsmotiv. Det gælder også - og måske især - $\mathrm{i}$ den udstrækning en sådan handling er nødsaget til at tilsidesætte det etiske hensyn for at nå det opstillede mål. Med Berlusconis egne ord hedder det: "På dette grundlag [...] giver Machiavelli fyrsten gode råd til, hvordan denne skal optræde i alle tænkelige situationer. Ud af dette kommer der et sæt af normer og anvisninger, der bevarer en enestående gyldighed også i vore dage, ikke bare for de få øverst på magtens pyramide, men også $\mathrm{i}$ almindelighed for alle dem, der har stillinger med ansvar". Det er nærliggende heri at finde en læsenøgle til at forstå Berlusconis egen vej mod toppen og med ham hans klan af forretningsvenner, advokater og almindelige ja-sigere.

Men hvad var det så for en situation, som Berlusconi agerede i, tog på sig og gav en retning? Hvad var det, der gjorde, at Berlusconis aktionsradius og indflydelse fik det omfang, som det har været tilfældet? Og hvad er det, der har forvandlet et liv som Berlusconis, en for så vidt ganske almindelig norditaliensk forretningsmands liv til at blive et ikonificeret emblem på en hel samfundstilstand, der for længst har suspenderet de gængse etiske og politiske tyngdelove, som ellers plejer at bestemme de sociale op- og nedture i et demokrati? Vi skal altså have nogle koordinater på plads for at få en idé om det historiske råderum, som Berlusconi arbejder i. Jeg vil her først kort skitsere de bredere rammer for så mere indgående at gå ind i de særlige italienske forhold.

For så vidt angår de bredere historiske og politiske koordinater sker der noget ved overgangen fra 1970'erne til 1980'erne. Mange iagttagere har således hævdet, at disse skæringsår netop varslede afslutningen på en såkaldt 'gylden tid', som havde karakteriseret efterkrigstiden, altså de lidt mere end tredive år fra midten af 1940'rne og frem til omkring 1980. Det var en periode, da et langt økonomisk opsving ikke bare sikrede en udvidet produktion og et større vareudbud men 
også lagde nogle forudsætninger for en større social retfærdighed, der kunne indfri mange af de forventninger til et velfærdsløft inden for forsorg, uddannelse og sundhed, som den italienske, demokratiske forfatning fra 1948 lagde op til. I Italien talte man om et økonomisk mirakel med meget høje vækstrater, og som også i begyndelsen af 1960'erne blev fulgt op af en centrumvenstre-reformpolitik. Det var en periode, hvori økonomien fortsat var forankret i en bestræbelse på at forene vækst og fordelingspolitik. I Italien blev denne blandingsøkonomi mellem en privat kapitalisme og en socialstat overordnet varetaget af Det kristelige Demokrati, om end der var flere eksempler på, at kommunisterne i PCI lokalt tog over. Det var tilfældet eksempelvis i regionen Emilia Romagna med mønsterbyen Bologna.

Denne model blev - groft set - anfægtet med den neoliberalistiske drejning, som den globale økonomi tog i 1980'erne under Ronald Reagan og Margaret Thatcher og yderligere blev accelereret, da Muren faldt i 1989 og Sovjetblokken kollapsede. Det var dengang den amerikanske politolog Francis Fukuyama proklamerede, at Historien var slut, og at markedsøkonomien og det liberale demokrati havde vundet den store historiske test. Det var nu ikke længere kun varerne, der flød frit rundt i verdens$ø$ konomien. Der blev slækket på restriktionerne. Det åbnede for et frit og fortsat mere dereguleret kapitalflow. Bankerne opfandt nye typer produkter, der brød med de principper for god bankskik, som den gamle Glass-Steagall Act (fra 1933) indførte efter 1929-krisen med et krav om at adskille almindelig bankvirksomhed og mere risikofyldte investeringsaktiviteter. Det betød, at enorme kapitalmængder nu blev overført bl.a. til et mere lukrativt kinesisk marked med det resultat, at Europa mistede arbejdspladser og visse steder helt er blevet afindustrialiseret. Det betød også, at der blev frigjort midler til rene spekulationer og tvivlsomme lån, mens store dele af gevinsterne havnede i de mange skatteparadiser og belastede de nationale statsbudgetter med tilsvarende skatteunddragelser og underskud.

De nationale politiske klasser stod magtesløse, efter at beslutningerne var flyttet over til de anonyme og uigennemsigtige finansmarkeder, der via de amerikanske ratingbureauer Moody's, Standard \& Poor's og Fitch nu også af og til kunne afgøre hele staters skæbne. Neoliberalismens fortalere fra bl.a. the Chicago School of Economics og The Washington Consensus, var af den opfattelse, at markederne var bedre til at fordele klodens ressourcer på deres egne vilkår, men overså, at overladt til sig selv ville den kapitalistiske produktionsmåde falde tilbage i sine cykliske kriser.

Jeg vil hævde, at forretningsmanden og mediemogulen og senere også politikeren Berlusconi om nogen eksponerede denne generelle dereguleringstendens i Italien og dermed bidrog til at tømme det politiske initiativ for, hvad der må anses for at udgøre politikkens overordnede mål, nemlig at sikre 'det gode styre', dvs. vækst og social retfærdighed inden for rammerne af de fælles accepterede institutioner, der i store træk havde tegnet de første tre årtier efter krigen. Det store historiske kompromis, som Det kommunistiske Partis leder, Enrico Berlinguer, og Det kristelige Demokratis præsident, Aldo Moro, stod som de førende eksponenter for, blev definitivt skrinlagt, da De Røde Brigader i 1978 bortførte og dræbte denne sidste. 
Dermed var det også definitivt forbi med de mere langsigtede politiske projekter i forlængelse af det samarbejde mellem de store folkelige partier, der bagom de åbenlyse modsætninger allerede havde ført til vedtagelsen af den første demokratiske og republikanske forfatning tilbage i 1948 .

1980 'erne betød en langsom afvikling af den gamle politiske klasse og af efterkrigstidens politiske kultur. Kommunistpartiet blev isoleret og gik omkring 1990 i opløsning og optrådte derefter under forskellige partibetegnelser og $\mathrm{i}$ forskellige kombinationer for i 2007 at genopstå som Partito Democratico. De kristelige demokrater og Socialistpartiet under ledelse af årtiets stærke mand, Bettino Craxi, sandede til i en stadig mere udbredt korruption, samtidig med at statsgælden voksede til det høje niveau, vi kender i dag. Politik handlede nu i højere grad om privatpersoners adgang til at få andel i statens ressourcer.

De store korruptionsskandaler i begyndelsen af 1990'erne, der blev afsløret under overskriften 'Operation Rene Hænder', fejede endegyldigt den gamle politiske klasse til side. Det var en i sig selv ubetydelig plejehjemsbestyrer, der igangsatte hele lavinen. Mario Chiesa hed han. Han var medlem af Craxis Socialistparti. Som bestyrer for en offentlig institution i Milano modtog han bestikkelse fra eksempelvis rengøringsselskaber, der kun kunne forvente at fà entreprisen mod en lille erkendtlighed under bordet. Dette stykke mikrohistorie var blot et ud af mange lignende eksempler, skulle det vise sig. Flere blev dømt, og enkelte som Bettino Craxi gik i eksil og døde i 2000 i udlændighed i Tunis.

Der bredte sig hurtigt den forventning, at betingelserne nu var til stede for en genrejsning af den offentlige moral. Denne forventning til politikkens genkomst som andet og mere end bare at rage til sig og fordele byttet blev dog ikke indfriet. Tværtimod tog globaliseringen af verdensøkonomien en vending, da det endnu spinkle monetære samarbejde i Europa blev udsat for et massivt spekulationspres. Det tvang den italienske lire ud; og den italienske stat blev endvidere tvunget til at privatisere flere af de store statskontrollerede industrier for at skabe lidt luft omkring den offentlige økonomi. En af disse var Italsider, det store jernværk med 12.000 beskæftigede i Taranto i Syditalien, der i 1995 blev opkøbt af private kapitalkræfter omkring familien Riva, men som i dag er lukningstruet pga. forurening, korruption og dårlig management.

Det var i dette pludseligt opståede magttomrum, at Berlusconi og entouragen omkring ham besluttede sig for at gå ind i valgkampen i 1994 og også fik en sejr i hus. Centrum-venstrefløjen stod ellers til at vinde, men havde klart undervurderet den enorme drivkraft bag Berlusconi og hans allierede, Den norditalienske Liga og nyfascisterne i MSI, senere Nationalalliancen. Berlusconis officielle begrundelse for at træde ind på den traditionelle politiske scene var stærkt farvet af den neoliberalistiske tankegang. Han pegede på sig selv som en succesrig forretningsmand, der af netop den grund skulle være så meget bedre egnet end de foragtede levebrødspolitikere til også at trimme staten og stå i spidsen for forretningen Italien. Selv om det lykkedes Berlusconi at vinde det ene valg efter det andet, blev disse forventninger langtfra indfriet, hvad der havde ikke så lidt at gøre med, at hans politiske entré også var motiveret af, at hans koncern skrantede lidt og i øvrigt var 
truet af de retssager, der var begyndt at tikke ind i kalenderen.

Faktisk blev han i november $2011 \mathrm{fæl}-$ det som statsminister, da de internationale finansmarkeder under den galopperende internationale økonomiske krise pressede Italien så hårdt, at forretningen Italien var på sammenbruddets rand, som Grækenland allerede var det. Men Berlusconi havde ikke en politik og et parlamentarisk flertal bag sig, hvorfor den daværende og nu også genvalgte præsident Giorgio Napolitano måtte skride ind og indsætte en teknisk regering under ledelse af Mario Monti, der skulle afværge det værst tænkelige og genskabe udlandets og EU's tillid til Italien.

Man kan således sige, at Berlusconi førte det neoliberalistiske budskab $a d a b$ surdum, altså ud i sin yderste konsekvens, og dermed også kom til at afsløre det katastrofeperspektiv, der lå i dette budskab. Det skal så tilføjes, at dette katastrofeperspektiv blev yderligere forstærket af de særlige italienske forhold, der befordrede hans opdrift i det italienske samfund allerede ved overgangen til 1980'erne og i flere etaper, der kunne sammenlignes med en tretrinsraket. Der er, vil jeg sige, tre kilder til den kolossale magt, som Berlusconi har opbygget, og som har sikret ham en så stærk position i det italiensk samfund de sidste tre årtier. Der er den økonomiske, den symbolske og den politiske kilde, som Berlusconi har haft en enestående evne til at forene med en helt utrolig og nærmest synergetisk effekt, ikke bare for hans egen sociale mobilitet, men også for de kræfter i det italienske samfund, som altid har haft denne nærmest anarkistiske trang til at være fri af snærende bånd og opfattet staten som en fjende at trodse, og som derfor aldrig rigtigt har accepteret den demokratiske retsstats principper, som disse blev nedfældet i forfatningen fra 1948. Det er her, at Berlusconi for alvor skiller sig ud fra så mange andre samtidige ledere i Europa.

Den første kilde vedrører spørgsmålet om, hvordan Berlusconi har tjent sin første lire og tilvejebragt den kapital, som først gjorde ham til byggematador i Milano, hvor han stod bag en række nye satellitbyer som Milano Due, og siden på baggrund af erfaringerne med kabel-TV i det nye byggeri til ejer af tre TV-stationer (Canale 5, ItaliaUno og ReteQuattro), der indgår i Mediaset. Mange undersøgelser af dette spørgsmål har peget på mafiaen, om end der aldrig er kommet noget klart svar. Der er dog en række forhold, som underbygger hypotesen. Således ansatte Berlusconi i perioden 1974-75 en vis Vittorio Mangano på sin nyerhvervede villa $\mathrm{i}$ Arcore, uden for Milano, med opgaver inden for close protection. Denne Mangano var imidlertid den sicilianske mafiaboss Pippo Calòs betroede mand i Norditalien, og vi ved fra retsmaterialet, som den myrdede offentlige anklager Paolo Borsellino har løftet en flig for i et interview, at Mangano var en slags brohoved for mafiaens hvidvaskningsaktiviteter i og omkring Milano, der altid har været Italiens økonomiske og finansielle centrum.

Dernæst er en af Berlusconis nærmeste medarbejdere, Marcello dell'Utri, ved flere retsinstanser, senest her i marts måned, faktisk blevet dømt flere års fængsel for, hvad man i juraen kalder ekstern støtte til mafiaen. Dell'Utri var direktør for Publitalia, som varetog en af Berlusconis Fininvest-koncerns vigtigste indtægtskilder, nemlig indtægterne fra TV-reklamerne. Samme dell'Utri har altid omtalt den nævnte mafioso Vittorio Mangano 
som en helt. Man kan med dagbladet $\mathrm{La}$ Repubblicas grundlægger og mangeårige chefredaktør Eugenio Scalfari sige - og det gjorde han tilbage i 2004 -, at hele den gråzone, der er mellem mafiaen og det omgivende samfund, altid har været "en integreret del af Fininvests historie".

En anden af de mange gråzoner omkring Berlusconi og hans entourage gælder forholdet til den hemmelige loge P 2 ('Propaganda Due'), som den undrende offentlighed fik indblik i i 1981, da aviserne offentliggjorde en liste over logens medlemmer, der talte mange fra det italienske establishment. Silvio Berlusconi var en af logebrødrene med medlemsnummeret 1816/0625. En af de få domme, Berlusconi har fået, hidrører netop fra, at han bevisligt har løjet om sit medlemskab af $\mathrm{P} 2$, som en parlamentarisk undersøgelseskommission i 1984 nåede frem til var i strid med forfatningen. P 2-kredsen udarbejdede således allerede i midten af 1970'erne ved logens stormester Licio Gelli en såkaldt 'Genfødselsplan' for Italien, der lagde op til en højredrejning af det italienske samfund på et tidspunkt, hvor Det italienske Kommunistparti vandt frem ved en række valg. Licio Gelli mente, at forfatningen gav for meget plads til kommunisterne og derfor ikke i sig selv var nogen garanti for det ønskede formål. Tværtimod. Der skulle andre midler til.

Et af de centrale punkter i Gellis 'Genfødselsplan' - og af interesse i denne sammenhæng - er det punkt, der taler for et brud med den monopolstilling, som public service stationen RAI (Italiens svar på DR) hidtil havde indtaget på TV-og radio-området. Der var allerede taget fat om dette centrale spørgsmål, da Forfatningsdomstolen netop i midten af 1970'erne i en række kendelser lagde op

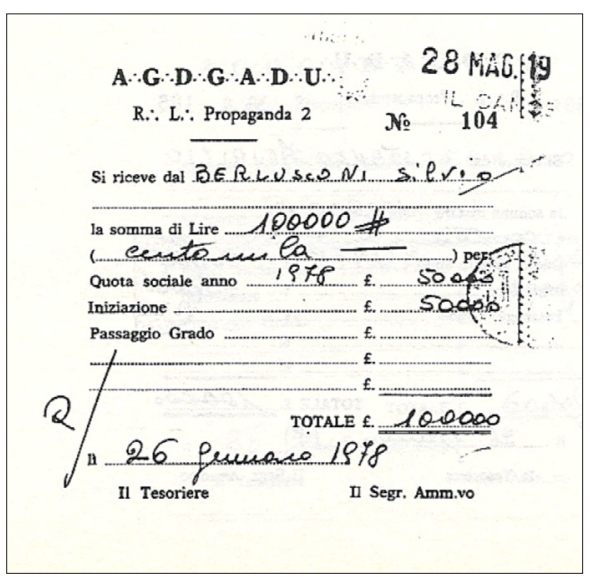

Kvittering for Silvio Berlusconis indmeldelse $i$ Propaganda Due, 26. januar 1978. A.G.D.G.A.D.U. er italiensk for frimurerudtrykket "Alla Gloria del Grande Architetto dell'Universo." Wikimedia Commons.

til en liberalisering på medieområdet, der kunne tillade private aktører i det civile samfund at komme på banen. Domstolen henviste til Forfatningens artikel 21 om ytringsfriheden. Set i lyset af den generelle venstredrejning i det italienske samfund ville det være nærliggende at læse dette udspil som en styrkelse af de civile rettigheder. Der poppede da også snart et stort antal lokalradioer op med tilknytning til de forskellige politiske og sociale bevægelser, og endnu flere med mere kommercielle interesser. Når P 2-kredsen tog dette op som et særskilt punkt, havde det utvivlsomt noget at gøre med et ønske om at styre denne liberalisering på medieområdet $\mathrm{i}$ en bestemt retning. Man bemærker derfor, at Berlusconi var medlem af logen i de år, hvori han flyttede sine økonomiske interesser fra bygge- til mediesektoren. Om nogen blev han den person, der legemliggjorde opkomsten af det, som den store medieforsker og forfatter Umberto Eco en gang kaldte neo- $T V$, 
altså det private, reklamefinansierede TV, der gik efter høje seertal snarere end efter de idealer for dannelse, information og oplysning, som public service stationen RAI formelt var forpligtet på, men dog langtfra indfriede. Det blev denne model, der kom til at præge dagsordenen på medieområdet.

En tredje af de gråzoner, hvori Berlusconi har bevæget sig og via diverse gunstbevisninger og vennetjenester fået sig arbejdet op til den økonomiske position, han hurtigt fik i 1980'erne, finder vi i Berlusconis særlige forhold til årtiets mest markante politiske skikkelse, nemlig Det socialistiske Partis leder Bettino Craxi. Craxi havde et godt øje til Berlusconi, fordi han i Berlusconi og hans revolutionering af medierne så et middel til at bryde den gamle politiske kultur op, som kommunisterne og de kristelige demokrater stod for, og dermed til at bane vejen for, at hans eget parti, Det socialistiske Parti, kunne blive det nye dominerende midterparti. Craxi tog den begyndende neoliberalistiske retorik til sig, når han $\mathrm{i}$ perioden som ministerpræsident brystede sig af, at nu havde det italienske bruttonationalprodukt overhalet det engelske.

Craxi udstak linjerne for en tredje vej, og han var måske i virkeligheden også forud for andre europæiske socialister som Felipe González og Tony Blair, der i samme grad men med større held omdannede de gamle arbejderpartier til middelklassepartier, nu hvor globaliseringen begyndte at tegne konturerne til en ny social sammensæxtning med en stadig større middelklasse flankeret på den ene side af en lille fortsat rigere elite og på den anden side af diverse udstødte socialgrupper.

Berlusconi blev Craxis protegé. Hvad det konkret betød, fik man et vidnesbyrd om, da myndighederne pludselig inddrog Berlusconis sendetilladelser og hans kanaler gik i sort. Baggrunden for dette indgreb var, at Berlusconi var begyndt at sende landsdækkende. Strengt taget havde Forfatningsdomstolen i sine kendelser tilbage i midten af 1970'erne kun givet tilladelse til at sende lokalt. Craxi tog derfor et hurtigt initiativ og vedtog et dekret, der tillod Berlusconi at gå i luften igen - også fordi folk protesterede over, at den sorte skærm forhindrede dem i at se TV-serierne Dallas og Smolferne. Dette dekret blev blot forlænget de følgende mange år, og betød i realiteten, at en egentlig lovgivning først kom på plads i 1990, dvs. på et tidspunkt, hvor Berlusconi i skyggen af sin mægtige beskytter og skytsengel kunne skabe sig et monopol på det kommercielle TV's område ved siden af RAI, altså et duopol, som den senere lovgivning blot stadfæstede.

Det gjorde det herefter svært for andre private investorer at komme ind på det lukrative marked. Efter vennetjenesternes logik kan det ikke forbavse, at Berlusconi faktisk betalte Craxi og hans parti for denne tjeneste. Dette eksempel på ulovlig finansiering af et parti endte da også senere i retten, efterhånden som man fik underretning om den udbredte korruption op igennem 1980'erne. Selv om det kriminelle forhold her har kunnet verificeres, er Berlusconi aldrig blevet dømt, da sagen faldt pga. forældelsesfristen, og dermed ikke fordi den anklagede blev frikendt.

Vi kan altså se, at Berlusconi konsoliderede sin Fininvest-koncern og sine særlige medieinteresser i selskabet Mediaset sideløbende med nogle politiske tiltag fra Craxis side, der ikke bare begunstigede Berlusconi ved at udsætte en egentlig me- 
dielovgivning, men som også bidrog til at svække de gamle kristeligt-demokratiske og især kommunistiske politiske kulturer.

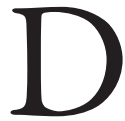
ermed er vi på vej over i den anden kilde til Berlusconis enorme indflydelse, nemlig den, der har sit udspring i den symbolske magt, som det nye TV har. Den symbolske magt er knyttet til de forestillinger, til de forventninger og til de prioriteringer og værdier, som de elektroniske medier formidler. Den symbolske magt bæres frem af de verbale og ikke-verbale sprog, af de billeder og af den redaktionelle framing, der via skærmen formgiver vor virkelighedsopfattelse. Formålet med det kommercielle TV er for så vidt klart nok. For det første gælder det om at tjene penge via reklamer: Jo flere seere, desto bedre bliver disse reklamer betalt, og desto mere er annoncørerne villige til at betale. Og for det andet gælder det om at stimulere seerne til som forbrugere at købe de varer, der reklameres for, og som kæmper om forbrugernes gunst. Der ligger her en helt afgørende alliance mellem mediets operatører og økonomiske bagmænd og erhvervslivet, der stiller andre interesser i skyggen. Denne prioritering i udgangspunktet gør, at marketing og fokusgrupper også bliver bestemmende for, hvordan programlægningen i øvrigt skal frames. For reklamebranchens Mad Men handler det ikke så meget om at forholde sig til et behov, som eksisterer, men om at overbevise forbrugeren om et behov, som denne ikke vidste, han eller hun havde. Det handler om at fà en vare solgt, jo, men nok så meget om at forme en livsstil, der forankrer et bestemt forbrugsmønster i vor individuelle hverdag. Den kendte polsk-engelske kulturfilosof Zygmunt
Bauman siger meget klart, hvad det får af konsekvenser for det enkelte individs prioriteringer, for hvad det enkelte individ synes er vigtigt: "Det individuelle behov for personlig autonomi, selvdefinition, autentisk liv eller personlig perfektion" erstattes nu i overvejende grad af et "behov for at besidde og forbruge varer, der tilbydes på markedet. Denne overføring drejer sig imidlertid snarere om, hvordan disse varers brugsværdi fremtræder, end om hvordan brugsværdien er i sig selv. Som sådan er den grundlæggende utilstrækkelig og i sidste ende selvmodsigende, da den fører til midlertidig imødekommelse af ønsker, men også til vedvarende behovsfrustration".

Denne forskydning af det nye TV's - hvad skal vi sige - 'pædagogiske' sigte smitter af på stationernes øvrige programlægning, altså den del - og i øvrigt stadig mindre del - der ikke fyldes ud med reklamer. Nyhedsdækningen bliver til infotainment eller politainment og hvad man ellers kan forestille sig af hybride genrer. Som seer kan det være svært at afgøre, hvorhenne man er i programflow'et. Er man midt i et reklamespot, et livsstilsprogram, en film, en sitcom, en soap eller $i$ et nyhedsprogram, eller måske er det underholdningsafdelingen, der har taget over? Denne forvirring er ikke blevet mindre af, at vanerne foran skærmen er ændret. Ofte kommer en seer ind midt i et indslag. Det ligger lige for, når man sidder med fjernbetjeningen. Men når man som seer ikke ser et program fra begyndelsen, kan det ikke sjældent være vanskeligt at afkode dets karakter.

Den politiske debat rykker fra de store pladser og fra partisektionerne ind i de mange talkshows, der ved siden af parlamentets to kampe nærmest har fået status 
af parlamentets tredje kammer, hvor det er blevet vigtigere for politikeren at optræde, med det resultat, at samfundets store spørgsmål forsvinder i smalltalk og almindeligt mundhuggeri. Hele hensigten med det større medieudbud, nemlig at sikre ikke bare en mere alsidig meningsdannelse men også en mere kvalificeret underholdning via en øget konkurrence, er på mange måder slået over i det modsatte, et massedistraktionssamfund, der har svært ved at koncentrere sig og sætte fokus på det væsentlige.

I denne uafbrudte strøm af billeder, lyd og tale taber den traditionelle politikertype terræn. Der er ikke plads og tid til eksempelvis en Aldo Moro eller Enrico Berlinguers lange udredninger. For overhovedet at blive synlig på den lille skærm og dermed skaffe sig ørenlyd kræver det, at politikeren fatter sig i korthed og fængende. Der er for så vidt heller ikke plads til de store intellektuelle og kulturpersonligheder, der tidligere fyldte op i den offentlige debat. Filminstruktøren Federico Fellini brokkede sig engang over, at en portrætudsendelse om og med ham hele tiden blev afbrudt af reklamer. Det var nærmest at sammenligne med graffiti på en fredet husmur.

I stedet er de optrædende i de nye reality-programmer ('Big Brother' eller 'Grande Fratello', som det hedder på italiensk), og alle de mange ankermænd eller ditto -kvinder, der styrer seerne og et indbudt publikum ind $i$ en verden af quizer og konkurrencer og halvbare dansepiger, og ikke at forglemme aftenens vindere med de 15 minutters berømmelse; det er alle disse, der er blevet de nye meningsdannere og lægger standarderne. Det er næppe tilfældigt, at Berlusconi har skudt millioner i det internationale produk- tions- og distributionsselskab Endemol, der har hovedsæde i Holland og er grundlagt af de to hollændere Joop van den Ende og John de Mol. Selskabet står bag eksempelvis 'Big Brother' og snesevis af andre, lignende koncepter. Det klassiske uddannelsessystem fra skole til universitet og hele den almendannelse, der traditionelt er knyttet dertil, er i de seneste årtier blevet stærkt udfordret af medierne og den særlige logik, der dominerer disse og nærmest er blevet et alternativt lærerum med et - skulle det vise sig - overrumplende politisk potentiale.

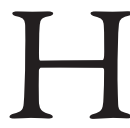

vad har alt dette med Berlusconi at gøre? Berlusconi forstod mediernes egen logik før alle andre. Det skabte den uomgængelige succes, han høstede ved at investere sin kapital i medierne. Men han forstod også før alle andre, at der i medielogikken, i mediernes måde at etablere opmærksomhedsskabende relationer til seerne, lå kimen til en ny form for politisk kommunikation, der ikke så meget henvendte sig til vælgerne som borgere men først og fremmest som forbrugere og seere, der skal have deres fornødenheder dækket her og nu - eller bedre endnu; deres forventninger stimuleret. Således nøjedes Berlusconi ikke bare med at stå som ejer af sine medier og stille sig til rådighed for de erhverv, der ville reklamere for deres varer. Han trådte selv ind i disse medier og optrådte hjemmevant og forstod hurtigt at tilpasse sig og sin krop til de nye spilleregler og blive det politiske ikon, den berømthed, han uomtvistelig er, og som ubesværet optræder både på de bonede gulve og i ugebladenes sladderspalter, inklusiv den meget sete hjemmeside Dagospia, der eksponerer kendislivets vulgariteter. 
Her op til valgkampen den 24.-25. februar var Berlusconi en flittig gæst i de mange talkshows. Han dukkede også op hos en vis Michele Santoro, der bestyrer programmet Servizio pubblico på en af de få mindre, private stationer, La7, der har haft held til at bryde Mediasets monopol. Sammen med den skarpe journalist Marco Travaglio har Santoro altid været blandt Berlusconis værste kritikere. Mange mente efterfølgende, at den 76-årige Berlusconi faktisk kom sejrrigt ud af den duel, der i scenografien var lagt op nærmest som en spansk corrida.

Det politiske potentiale, der lå i medierne som et alternativt politiskpædagogisk rum, forstod allerede den kontroversielle forfatter og filmmand Pier Paolo Pasolini. I nogle artikler og interviews til Milano-dagbladet Corriere della Sera fra midten af 1970'erne, kort før sin død for morderhånd i 1975, kredsede Pasolini sig ind på, hvad han kaldte en antropologisk mutation eller en antropologisk revolution, som han mente at kunne spore i italienernes ændrede forventninger til deres liv og til en fremtid, der ikke længere blev defineret af den gamle bondekultur, af den gamle kristne-katolske kultur endsige af industriarbejdernes kultur. Udgangspunktet for hans på mange måder ganske visionære overvejelser var folkeafstemningen i 1974 om en få år gammel skilsmisselovgivning, som de kristelige demokrater på Fanfanis foranledning ønskede at ophæve. Imidlertid led Fanfani et nederlag og fik ikke et flertal for lovens ophævelse. Det blev af tilhængerne udlagt som en klar sejr for de verdslige kræfter i det italienske civilsamfund og en sejr for de civile rettigheder, der var indskrevet $\mathrm{i}$ Forfatningen af 1948.
Pasolini gik imod den euforiske stemning, da han i resultatet derimod så en anden tendens, der ikke havde så meget at gøre med en styrkelse af de verdslige værdier. For ham tegnede der sig snarere en helt ny horisont, der mere pegede på en frisættelse af lige præcis den type individ, der havde sig selv som eneste fokus, og som derfor var så meget mere i overensstemmelse med de modeller for en mere individualistisk livsstil, som forbrugersamfundet opererede med. Pasolini nærede ikke tvivl om, at denne for ham at se dybe, antropologiske omstilling, blev befordret af en tilsvarende ny type magt, der tømte de mere medborgerrettede traditionelle politiske kulturer for gennemslagskraft. Pasolini indrømmede dog, at han ikke kunne sætte et ansigt på denne nye type magt.

Mit bud er, at med Berlusconi kan vi bedre forstå, hvad der egentlig lå i Pasolinis antydninger. Det er Berlusconi, der har høstet de politiske frugter af denne antropologiske mutation, ja han har selv været en drivkraft i denne mutation, der for alvor blev synlig i 1980'erne og banede vejen for Berlusconis entré på den politiske scene. Berlusconis højre hånd, chefen for Mediaset, Fedele Confalonieri, udtrykte det på denne rammende måde: "Folk forstår ham, mange millioner af italienere identificerer sig med ham, fordi de er trætte af partier og bureaukratier ... Han har forstået at forandre 1970'ernes og terrorismeårenes grå klima. Han har indført lidt mere Amerika og mere forbrug, mere munterhed og mindre bigotteri. Dette er politik i ordets egentlige betydning".

Og hermed er vi ovre i den tredje og sidste kilde til Berlusconis magt, som jeg her vil se på. Det interessante ved 
Confalonieris udsagn er jo, at han ser en ny politikopfattelse eller måske rettere en oprindelig politikopfattelse opstå eller genopstå med indførelsen af det private reklamefinansierede TV i 1980'erne. Men det var først fra valget i 1994, at Berlusconi indledte sin karriere som politisk leder i den traditionelle, parlamentariske forstand af ordet; inden han gjorde det, var den forudgående kulturkamp allerede udkæmpet og vundet. Enkelte af de punkter, jeg vil nævne nu, har man igennem årene løbende kunne læse i aviserne her i Danmark. Det gælder de mere flamboyante detaljer om Berlusconis privatliv. Men som jeg har prøvet at lægge det frem her, så er det kun toppen, et kulminationspunkt, der hviler på en række forudsætninger, der normalt ikke indgår i den løbende 'nyhedsdækning' af Berlusconis Italien i Danmark.

Berlusconi lancerede sin valgkamp i 1994 ved at udsende en video, der uredigeret blev sendt på alle de kanaler, som han havde uhindret adgang til. RAI holdt sig imidlertid heller ikke tilbage. Det falder naturligvis helt i tråd med mediernes egen invaderende logik, men det rimer ikke helt med den politiske korrekthed, han prøver at lægge for dagen i selve valgvideoen, hvori han pointerer at ville løse den interessekonflikt, han befinder sig i som politisk leder og medieejer på én gang. Det sker dog aldrig. I øvrigt var Berlusconi slet ikke valgbar, skulle man henholde sig til en gammel paragraf fra 1957, der udtrykkeligt udelukker kandidater, som samtidig driver privat virksomhed på grundlag af offentlige licitationer, hvilket Berlusconi faktisk gør.

Interessekonflikten er aldrig blevet løst og har heller aldrig været et problem for de millioner, der har stemt på ham.
Berlusconi synes allerede her at omgærde sig med en immunitet, en urørlighed, som netop besiddelsen også af en snæver politisk magt - ved siden af den økonomiske og symbolske magt - yderligere har styrket. Som ministerpræsident i flere omgange og med et parlamentarisk flertal bag sig kunne Berlusconi uhindret tilrettelægge lovgivningen på en sådan måde, at det blev endnu vanskeligere at retsforfølge ham i de mange sager, han stod anklaget i. For at lette lovgivningsarbejdet blev Berlusconis personlige advokater, der varetog hans interesser i retssalen, også valgt ind som deputerede for hans parti (først Forza Italia og siden Frihedens Folk, Il Popolo della Libertà). De vidste jo, hvor skoen trykkede. Berlusconi prøvede flere gange at få en egentlig immunitetslovgivning igennem, der ville forhindre en fortsat retsforfølgelse, så længe han var ministerpræsident. Disse initiativer blev efter langvarige juridiske drøftelser erklæret for forfatningsstridige af Forfatningsdomstolen med henvisning til at de brød forfatningens princip om lighed for loven. Men manøvren havde imidlertid det ene formål at forsinke de løbende sager. Det lykkedes, da Berlusconi hidtil har unddraget sig en dom. I mange af tilfældene har det kriminelle sagsforhold kunnet bevises. Sagen er så afsluttet, fordi den er blevet forældet efter en anden lovgivning, der bekvemt har nedsat tiden for en sags forældelsesfrist. Der er dog i hvert fald totre sager, hvis udfald endnu er uvist. Det gælder en skatteunddragelsessag, ifølge hvilken Berlusconi skulle have oprettet en række skuffeselskaber, der købte og solgte filmrettigheder. Fortjenesterne herfra skulle således ikke være bogført men henlagt i skjulte fonde, der ellers typisk kan bruges til alternative og mere lyssky 
transaktioner, som f.eks. bestikkelse. Berlusconi har her fået en dom på fire år ved første instans. Det kan så trække ud, da der er yderligere to instanser.

Så venter en nyfigen offentlighed på, hvad der sker i den såkaldte Ruby-sag, hvori Berlusconi står anklaget for sex med en mindreårig og magtmisbrug, da han skal have ringet til politiet i Milano for at få løsladt den tilbageholdte marokkanske pige Karima El Mahroug (med kunstnernavnet Ruby) med henvisning til, at det drejede sig om en niece til den daværende ægyptiske præsident, Hosni Mubarak. Endelig har der været en sag under opsejling, der antyder, at Berlusconi kort efter at have mistet regeringsmagten i 2006 til en centrum-venstre regering under ledelse af Romano Prodi skulle have købt parlamentarikere fra det nye flertal i det klare øjemed at bringe Prodi til fald.

Med den politiske magt fulgte også en øget kontrol med medierne, ikke mindst de statslige medier. Benægtelse af virkeligheden og manipulation med virkeligheden har hørt til dagens uorden. Hvordan ytrer det sig? Vi har eksempler på, at Berlusconi har ringet direkte ind til et program, hvis han var utilfreds med, hvad der foregik. Han har fået kritiske journalister fjernet, bl.a. den føromtalte Michele Santoro. Han fået indsat loyale journalister på de vigtige poster som chefredaktører på TV-aviserne. Augusto Minzolini var en af disse. Han sad i en lang periode på den mest sete TV-avis på RAI 1, og gav den en utvetydig slagside. Da sagen mod den engelske advokat David Mills, der stod anklaget for at have modtaget penge fra Berlusconi mod at aflægge falsk vidnesbyrd i en af de sager, som Berlusconi selv var involveret $\mathrm{i}$, faldt pga. forældelse, blev det præsenteret som om den engelske advokat var blevet frifundet. Og så fremdeles. Berlusconis egne kanaler har heller ikke holdt sig tilbage fra at bruge mediet til en egentlig mediemobning, f.eks. blev en dommer, der havde idømt Berlusconi en bod på flere hundrede millioner i en erstatningssag, hængt ud og latterliggjort. Da den tidligere forkvinde for den mægtige arbejdsgiverforening Confindustria, Emma Marcegaglia, kritiserede Berlusconi for den førte økonomiske politik, var der allerede et dossier klart med forskelligt inkriminerende materiale mod hendes egne virksomheder, der blev brugt for at bringe hende i miskredit.

På denne måde fratages de store dele af befolkningen, der kun får deres informationer fra TV-mediet, muligheden for at vide, hvad der egentlig foregår. Får de så noget at vide, er det ofte usammenhængende og derfor i realiteten uforståeligt, hvorfor mange synker ned i et socialpsykologisk mix af kynisme, apati og indifference, der er nogle af berlusconismens mange sideeffekter.

Det er derfor næppe tilfældigt, at med Berlusconi er politikeren blevet en stand-up komiker. I denne henseende er Femstjernebevægelsens Beppe Grillo ikke den første. Vittighederne er blevet en integreret del af Berlusconis politiske kommunikation. De indstuderes ned i mindste detalje. De bruges gerne til at tage luften ud af de mere seriøse emner, som når han fortæller en historie om en mafioso og dennes søn, der spørger, om Einstein er død - emnevalget kan forekomme overraskende i de kredse. "Jo, svarer faderen. Einstein er død", "Men hvorfor?”, spørger sønnike. Hertil svarer faderen: "Han vidste for meget".

Berlusconi er med sin rigdom og sin livsførelse højt hævet over alle andre. Men 
han har altid i sin retorik og i sine virkemidler været tæt på sine mange vælgere, og han kender de stemninger, der rører sig blandt disse, og han forstår at omsætte disse stemninger til forventninger og indsætte sig som den, der kan indfri disse forventninger - også selv om de mange løfter ikke bliver holdt. Berlusconis demokratiopfattelse er populistisk og hviler alene på kontrakten mellem ham som leder og hans vælgere, der i valghandlingen så at sige deponerer al magt hos lederen og giver denne et carte blanche til at gøre, hvad han finder passende. Men et demokrati er ikke kun et flertalsstyre. Det er også et system af gensidige balancer og kontrolforanstaltninger netop for sikre, at den folkelige suverænitet respekteres og ikke monopoliseres af bestemte magtgrupper.

Synergien mellem disse tre kilder til magt (den økonomiske, den symbolske og den politiske kilde) er ganske udtalt i Berlusconis tilfælde. Han strøg til tops i det italienske samfund $\mathrm{i}$ kølvandet på den neoliberalistiske vending på den globale scene ved overgangen til 1980'erne og blev yderligere begunstiget af særlige italienske forhold. Men han blev også ramt af den globale krise, der har afsløret en indbygget krisetendens i den deregulerede markedsøkonomi, som selv ikke Berlusconi har kunnet bortforklare, trods ihærdige forsøg. Krisen og dens barske realiteter - recession, arbejdsløshed og fattigdom har defineret grænserne for berlusconismens vækst, om end fænomenet ikke er forvundet endnu. I november 2011 måtte Berlusconi overdrage regeringsmagten til Mario Monti. Men valgresultatet tilbage i februar har imidlertid givet ny luft til ham, i den udstrækning hans parti efter al sandsynlighed kommer med i en samlingsregering, som den genvalgte præsident, Giorgio Napolitano, har på trapperne. Den lange økonomiske krise vil dermed fortsat vidne om, at krisen først og fremmest er politisk-kulturel. Det er den ikke mindst efter de mange år med en ledelsesstil, der har været styret af en politisk kaste, formet i Berlusconis billede. Den desorientering og afmagt, som berlusconismen har efterladt, har så meget lettere ført til, at så mange millioner italienere har været til fals for demagoger og folketribuner.

\section{Litteratur}

Orsina, Giovanni: Il berlusconismo nella storia d'Italia. Venezia: Marsilio, 2013

Sørensen, Gert: Berlusconi og den moderne fyrste. Om demokratiets tilstand i et land i Europa. København: Museum Tusculanums Forlag, 2008.

Sørensen, Gert: "Berlusconi e la riorganizzazione postdemocratica del potere", Studi Storici, n. 2, aprile-giugno 2009, pp. 371-94. 